Research Square
Preprints are preliminary reports that have not undergone peer review.

They should not be considered conclusive, used to inform clinical practice, or referenced by the media as validated information.

\title{
Public financing in agricultural research development and rural poverty alleviation in West African Economic and Monetary Union (WAEMU) States
}

Ollo DAH ( $\sim$ ollodah41@yahoo.fr)

Thomas Sankara University

Toussaint Boubié BASSOLET

Thomas Sankara University

Research

Keywords: Public financing, agricultural research and development, rural poverty, WAEMU States

Posted Date: August 18th, 2020

DOI: https://doi.org/10.21203/rs.3.rs-57470/v1

License: (c) (i) This work is licensed under a Creative Commons Attribution 4.0 International License. Read Full License 


\section{Abstract}

This paper analyzed the effects of public funding for agricultural research and development on rural poverty reduction through farm income in West African Economic and Monetary Union (WAEMU) countries. To conduct this analysis, an agricultural production function was developed that integrates public policies. In view of the scope of the analysis, a dynamic panel was developed to take into account the dynamics of agricultural income. The data used in this research were mainly taken from the databases of the World Bank, the African Development Bank and the FAO and cover the period from 2000 to 2016. The data were estimated using the Generalized Moment Method (GMM) in system. The results show that public spending on agricultural research and development contributes to reducing rural poverty through increased agricultural income. Thus, it is recommended that WAEMU states make efforts in the allocation of public resources in the area of agricultural research and development to boost the development of the agricultural sector and significantly reduce rural poverty.

\section{1- Introduction}

Agricultural sector occupies a fundamental place in the economies of the West African Economic and Monetary Union (WAEMU). It contributes to about $34 \%$ of the Gross Domestic Product (GDP) and employs, depending on the country, between $65 \%$ and $85 \%$ of the active population. According to the BCEAO (2012), the main income-generating activity for the majority of the rural population is in the agricultural sector. According to the World Bank (2008), this sector can be a source of pro-poor growth in developing countries given the large number of poor people working in this sector. In the same vein, Timmer (2009) has shown the greater efficiency of the agricultural sector in reducing poverty compared to the non-farm sector. According to this author, GDP growth due to agriculture contributes at least two (02) times more to poverty reduction than that recorded by the non-agricultural sector. Christiansen et al (2010) study of 82 developing countries concludes that the effectiveness of agriculture in reducing poverty is generally higher, with the latter being particularly important for the very poor. This study puts forward a relative efficiency ratio of 3.2.

In WAEMU countries, poverty is more prevalent in rural areas where agriculture is the primary source of livelihood and employment. Thus, poverty reduction efforts must be concentrated in this environment. The crucial role of agriculture in poverty reduction in WAEMU countries is now recognized, but financing policies are still far from being commensurate with the weight that agriculture and its stakes represent (Bikienga, 2011). Most developing countries have not accorded agriculture and rural development a particular importance in their national development strategies. Underinvestment in essential public goods has limited the ability of these countries to respond to the opportunities offered by liberalization. In these countries, public spending on agricultural research and development accounts for only 0.6 per cent of agricultural GDP compared to 2.6 per cent in developed countries (Beintema and Pardey, 2002). In Africa, almost half of the countries saw investment in agricultural research and development decline in the 1990s (Beintema and Stads, 2004).

In 2014, the evaluation of the Maputo Declaration in 2003 where African Heads of State committed themselves to allocate a minimum of 10\% of the national budget to agriculture in order to achieve a $6 \%$ growth of the agricultural economy shows that the results are below expectations. On average, West Africa allocates $7 \%$ of public expenditure to agriculture. As far as agricultural growth is concerned, it has remained low, as evidenced by the high level of food insecurity and rural poverty (Wade and Niang, 2014).

Given the strategic nature of agriculture, policymakers have an important role to play in its financing. Public intervention appears to be a necessity in order to transform traditional agriculture into modern agriculture, which will increase agricultural productivity to reduce the number of rural poor. Farmers' training and research and development in agriculture have the characteristics of public or collective goods and therefore cannot be provided by farmers themselves. They are indispensable types of investment to improve productivity and require government intervention (Shyjan, 2007). Fan et al (2008) argue that spending on public goods in rural areas pays off. They show that agricultural research and education are the most effective forms of public spending to promote agricultural growth and reduce rural poverty.

The importance of research and development in increasing agricultural productivity and improving living conditions in rural areas seems to be proving itself following the experience of the Green Revolution. In Pakistan, for example, it has been estimated that almost $58 \%$ of total output growth from 1960 to 1996 was due to technological change (Ali, 2000). While improvements in physical and market infrastructure, farmer education, pricing policies and weather conditions all have their place in improving rural livelihoods, R\&D investment is considered by far the most important contributor to rural poverty reduction (Evenson and Rosegrant,1993; Byerlee,1994).

Poverty reduction remains one of the major economic policy challenges of recent years in WAEMU countries. Consequently, there is a need for vigorous, continuous and enlightened action. Consequently, policies focused on the financing of agriculture could improve job creation, raise incomes and thus reduce poverty. Several studies have been conducted to examine the relationship between public funding for research and development and agricultural sector development (Rosegrant et al, 1998; Thirtle et al, 2003; Govereh et al, 2006; Alene et al, 2009; Suphannachart and Warr, 2011; Borlaug, 2013). However, very little research to our knowledge has linked public funding for research and development to the income level of agricultural producers, especially in the context of the WAEMU, where countries are pointed out for their

Page 2/12 
under-investment in this sector, which is essential for development and poverty reduction. In addition, very little research has focused on a refined analysis of the effects of public spending on agricultural research and development on rural poverty. This paper attempts to fill these gaps by focusing on the effects of public spending on agricultural research and development on rural poverty. Better yet, a distinction is made between the effects of total public spending on agricultural research administration, the number of agricultural researchers and training. Thus, the general objective of this research is to study the effects of public funding for agricultural research and development on rural poverty in WAEMU countries. Specifically, this paper analyses the effects of total public spending on agricultural research administration, training and the number of agricultural researchers on rural poverty in WAEMU countries.

The rest of the paper is as follows. The second section presents the analysis methodology. The third section presents the results followed by discussion. The final section concludes by inferring policy implications.

\section{2- Empirical Strategy}

This paper examines how public spending, particularly on agricultural research and development, affects rural poverty. This work focuses on the provision of public goods because the primary responsibility of governments is to provide public goods that represent goods and services that are under-provided due to missing markets or market imperfections. Investment in public goods provides factors of production that are almost by definition rarely provided by the private sector. For this reason, such investment can reasonably be expected to fill a gap that is not filled by the private sector.

Spending on public goods generally produces benefits that tend to be more beneficial to the poor than the provision of private goods that are usually monopolized by lobbies. For example, an adequate stock of rural public goods, including agricultural research and development, can help to sustain farm incomes. Moreover, the rural sector in many developing countries is large enough in the unskilled labour market to significantly affect the real wages of unskilled workers, even at the national level (López (2004). Thus, a dynamic rural productive sector is a vital source of employment for unskilled workers because it can play a role in supporting higher real wages. Since most of the poor are unskilled workers, these effects can be important for poverty reduction.

\section{1- Model}

The theoretical model used in this research is based on that of López (2004). The author used this model to analyse the effects of rural public spending on agricultural growth and rural poverty in Latin America. The approach consists of specifying a reduced-form model that explains per capita agricultural value added by exogenous variables. It considers the following production function:

Where $\mathrm{Q}$ is agricultural output, $\mathrm{K}$ is a vector of farmer-owned inputs, $\mathrm{L}$ is labour used in the sector, $\mathrm{X}$ is a vector of purchased inputs, and $\mathrm{A}$ is a productivity index.

Agricultural value added is defined as the output of primary factors, K, L. Thus,

where $G()$ is agriculture GDP, $p$ is output price and $v$ is a vector of purchased input prices. The function $G()$ is a (dual) revenue function and must satisfy certain conditions: The most important from our point of view is that, apart from being increasing and concave in $L$ and $K$, is also homogenous of degree one in $\mathrm{K}$ and $\mathrm{L}$. This implies that we can express per capita agriculture GDP as:

Thus, per capita GDP is a function of output and purchased input prices, and the per capita values of the farmers owned assets, $k$, as well as of the productivity factor, $A$. It is increasing in $p, k$ and $A$, and decreasing in $v$. The remainder of this section is devoted to the estimation strategy of the per capita agricultural GDP function, . As a result, it is assumed that the prices of output and purchased inputs are determined by world prices, national policies including trade policy, as well as the performance of the non-farm sector that may affect marketed products. Thus, 
where a star indicates world prices, $\mathrm{H}$ stands for a vector of government policies affecting domestic prices and $\mathrm{Y}$ reflects conditions in sectors other than agriculture, but that could affect prices relevant to agriculture. The variables, $p^{\star}, \mathrm{H}$, and $\mathrm{Y}$ are all subject to change over time as world market conditions, policies, and non-agricultural growth conditions vary.

The variables $\mathrm{k}$ and $\mathrm{A}$ are also endogenous and affected by the exogenous variable, world market conditions, government policies and the performance of the non-agricultural economy.

It is assumed that the level of agricultural assets per capita $\mathrm{k}$ increases with rising agricultural prices, falling input prices and rising levels of agricultural productivity. Similarly, it is assumed that A increases with the level of public spending, particularly on public goods such as research and development and education. Government policies also affect the accumulation of agricultural assets per capita through both commodity and input prices, technical assistance, etc., and the level of agricultural productivity. Similarly, conditions in the non-farm sector affect agricultural value added through market effects associated with demand conditions for agricultural commodities, as well as through non-trade mechanisms. Combining (4) and (5) we obtain a reduced form function of $k$,

The $\mathrm{H}$ vector can be decomposed into several dimensions of government policies such as trade policies and public spending. In this work, the focus will be on public spending on agricultural research and development. Thus, we can decompose the $\mathrm{H}$ vector into $\mathrm{R}$ (public expenditure on agricultural research and development) and E (training policy) and T (trade policy).

Thus, $\mathrm{k}$ can be written as follows:

It is expected that $k$ does not decrease in $p^{*}, Y, R, E, T$ and does not increase in $v^{*}$. Substituting (4), (5) and (7) in (3) yields a specification of the reduced form of the per capita agricultural value added function

The signs under the variables indicate the expected effects of these different exogenous variables on per capita agricultural value added. Eq. (8) forms the basis for the specification of the estimation model.

Within the framework of this study, poverty is analysed through the monetary approach. This option is justified by the fact that it is monetary poverty that attracts the most attention from policy makers. Moreover, being linked to the level of household income, monetary poverty can be considered not only as a result of production conditions, but also as a consequence of the institutional arrangements that are put in place to stimulate the process of wealth creation (Savadogo et al, 2012). As a result, rural poverty is approximated to agricultural income. This choice is based on the fact that an increase in income is accompanied by a decrease in poverty. This option is supported by Kanbur and Squire (2000) who show that improving rural incomes is an important strategy for reducing rural poverty. Similarly, by agreeing with Boussard et al (2006), it is proven that poverty is linked to purchasing power and therefore income. The poor are those who cannot afford the goods needed to access a satisfactory level of available kilocalories.

Moreover, it is worth emphasizing the dynamic nature of income, which can generate a vicious circle of poverty over time without external intervention. Those who are poor year-round are more likely to be poor year-round. Therefore, poverty is analysed using a dynamic approach. It is therefore possible to adopt a dynamic model in which the lagged dependent variable is included as an additional explanatory variable to capture the potentially slow adjustment of agricultural value added to policies and other conditions. In the light of these arguments, the following sub-section defines the variables retained in the model. From (8) it is possible to deduce the agricultural income equation that will capture rural poverty.

\section{2- Data description}

The analysis is based on panel data covering the period 2000-2016. The study covers seven (07) countries out of the eight (08) WAEMU countries. Guinea Bissau was excluded from the analysis due to unavailability of data. The choice of the study period is linked to the availability of data on the variables. The data mainly come from the World Bank's World Development Indicators (WDI, 2017) database, the World Food and Agriculture Organization (FAO), and the African Development Bank (AfDB). 


\section{3- Definition of model variables}

\subsection{1- Dependent variable \\ Rural poverty indicator}

In this paper, the dependent variable is an indicator of agricultural income that is approximated to rural poverty. It is represented by the logarithm of the ratio of agricultural value added per capita to the international poverty line. Similar studies have used this indicator in their analyses. One can cite that of Savadogo et al (2012) which used this poverty indicator to analyse the standard of living of households in rural Burkina Faso in the context of decentralisation. Similarly, Sanfo (2010) analysed the effects of public agricultural policies on the fight against rural poverty in Burkina Faso using farm household income.

\subsection{2- Explained variables}

\section{Public expenditure on agricultural research and development}

Data on agricultural research and development expenditures (rdinvest) are provided by IFPRI and include expenditures related to the administrative operations of government agencies engaged in applied research and experimental development in agriculture. These expenditures include grants, loans and subsidies to support applied research and experimental development in agriculture carried out by research institutes and universities.

\section{The number of agricultural researchers per one hundred thousand $(100,000)$ producers (nagriresearch)}

The number of agricultural researchers per one hundred thousand $(100,000)$ producers (nagriresearch) was also included. This indicator, provided by FAO, includes all those with official researcher status employed by public agencies, non-profit organizations and higher education institutions to carry out studies in the agricultural field.

\section{Education}

The effects of education on rural poverty were also considered in the light of the theoretical and empirical literature. According to human capital theory, education improves the productivity of economic agents. Thus, a high level of education should be accompanied by a high level of income. Lau et al (1991) showed that education had an effect on agricultural productivity when the farmer had an educational level of more than three years. The authors carried out this study using data from more than fifty countries, including some West African countries. Moock (1981) and Rauf (1991) found similar results in the eastern region of Kenya. Thus, Primary completion rate (eduprim) was used to take into account the effects of education on agricultural income. A positive sign of this variable is expected. Table 1 provides a summary of the variables used and their sources. The expected signs are also presented.

\section{Value added of non-agricultural products}

This is the manufacturing sector, which includes tabulation category D in divisions 15 to 37 of the International Standard Industrial Classification (ISIC) of all economic activities. It is the physical or chemical transformation of component materials into new products, whether the work is done by machine or by hand, whether it is done in a factory or in the worker's home, and whether the products are sold wholesale or retail. This includes the assembly of components of manufactured products and the recycling of waste.

Value added is the net output of a sector after adding up all outputs and subtracting intermediate inputs. It is measured in current US dollars. This indicator is provided by the AfDB. A positive sign of this variable is expected.

\section{Trade Opening rate (openr) :}

It is given by the sum of exports and imports in relation to GDP. A positive sign is expected. According to the theory of comparative advantage (Ricardo, 1817), the absence of restrictions on trade can favour gains from trade. 
Table 1

Summary presentation of model variables

\begin{tabular}{|c|c|c|c|}
\hline $\begin{array}{l}\text { Variables of } \\
\text { model }\end{array}$ & Definition of variables & Source & $\begin{array}{l}\text { Expected } \\
\text { sign }\end{array}$ \\
\hline rinc & $\begin{array}{l}\text { Agricultural value added per capita relative to the poverty line of country } i \\
\text { at the date } t\end{array}$ & $\begin{array}{l}\text { Calculated by the author } \\
\text { from FAOSTAT data }\end{array}$ & $\begin{array}{l}\text { Dependent } \\
\text { value }\end{array}$ \\
\hline rinc $_{i t-1}$ & $\begin{array}{l}\text { Delayed one-year value of the log of agricultural value added per capita } \\
\text { relative to the poverty line of country i at the date } t\end{array}$ & $\begin{array}{l}\text { Calculated by the author } \\
\text { from FAOSTAT data }\end{array}$ & + \\
\hline rdinvest & Public spending on agricultural research and development & IFPRI database & + \\
\hline nagriresearch & Number of agricultural researchers per hundred thousand producers & FAOSTAT & + \\
\hline primeduc & Primary completion rate & AfDB database & + \\
\hline openr & Trade opening rate & $\begin{array}{l}\text { Calculated by author from } \\
\text { World Bank (WDI) data }\end{array}$ & + \\
\hline nava & Value added of the non-agricultural sector & $\begin{array}{l}\text { Calculated by author from } \\
\text { World Bank (WDI) data }\end{array}$ & + \\
\hline
\end{tabular}

\section{4- Empirical model specification}

The inclusion of income dynamics in the model leads to the following specification:

i represents the country and the time

is the log of agricultural value added per capita normalized to the international poverty line

represents public spending on education measured by total enrollment of primary students

represents public spending on agricultural research and development

number of agricultural researchers per 100,000 producers

is an indicator of trade openness

is the value of non-agricultural GDP per capita

represents the individual effects

is the error term

\section{5- Descriptive analysis}

Table 2 presents descriptive statistics. 
Table 2

Descriptive Statistics

\begin{tabular}{|llllll|}
\hline Variable & \multicolumn{1}{l}{ Observations } & Mean & Standard deviation & Min & Max \\
\hline \multicolumn{2}{|l}{ Variable dépendante } & & & & \\
\hline rinc & $\mathrm{N}=119$ & 1.214984 & .7969399 & .2365263 & 3.731752 \\
\hline Explanatory variables & & & & \\
\hline nagriresearch & $\mathrm{N}=119$ & 5.982426 & 2.436083 & 2.305695 & 9.868282 \\
\hline rdinvest & $\mathrm{N}=119$ & 29.11268 & 22.53258 & 5.498965 & 91.56726 \\
\hline openr & $\mathrm{N}=104$ & 62.63954 & 19.07883 & 27.86642 & 127.262 \\
\hline primedu & $\mathrm{N}=99$ & 51.04605 & 15.58608 & 18.87801 & 85.10817 \\
\hline nava & $\mathrm{N}=119$ & $1.08 \mathrm{e}+09$ & $1.17 \mathrm{e}+09$ & $1.08 \mathrm{e}+08$ & $5.74 \mathrm{e}+09$ \\
\hline
\end{tabular}

Table 2 shows that the rural poverty indicator represented by agricultural value added per agricultural asset normalized to the poverty line is on average US\$1.21. The maximum value observed is 3.73 US\$ recorded by Côte d'Ivoire in 2014 against a minimum value of 0.23 US\$ for Burkina Faso in 2000.

In terms of expenditure on agricultural research and development, the average for WAEMU countries is US\$ 29,112,680, with a maximum of US\$ 91,567,260 reached by Côte d'Ivoire in 2000, compared to a minimum of US\$ 5,498,965 recorded by Niger in 2000 . Concerning the number of agricultural researchers per 100,000 producers, UEMOA has an average of 6 researchers. Niger has more agricultural researchers (10) in 2011, whereas in 2008 it was the least endowed country with 3 agricultural researchers. In addition, it should be noted that the average primary completion rate is $51.05 \%$ with a maximum of $85.11 \%$ in Togo in 2014 against a minimum of $18.87 \%$ for Niger in 2000 .

For the control variables, the average value added of non-agricultural products amounts to 1.08 billion US\$ with a maximum of 5.74 billion US\$ recorded by Côte d'Ivoire in 2014 against a minimum of 0.108 billion US\$ recorded by Niger in 2000 . With regard to trade openness, the average observed over the period amounts to $62.64 \%$. The maximum value of trade openness is $127.26 \%$ and was observed in 2013 in Togo against a minimum value of $27.87 \%$ presented by Burkina Faso in 2013.

\section{6- Estimation method}

In Eq. (9), the lagged endogenous variable appears as the explanatory variable, so we are in a dynamic panel situation. In this case, standard econometric techniques such as OLS do not provide unbiased estimates of such a model. Indeed, the presence of the lagged explanatory variable makes the OLS and GCM estimators inefficient and non-convergent. Furthermore, when the number of periods is small or when the lagged dependent variable is correlated with individual effects, OLS estimation of this model leads to biased and non-convergent estimators. For Mickell (1981), in the case of inverse causality or omission of relevant variables, the OLS estimator is inconsistent and biased.

In the literature, GMM techniques are increasingly used to estimate dynamic panel models (Andrianaivo and Kpodar, 2011; Konté et al., 2017; Zmami, 2017; Amat, 2019). This method is adequate to deal with the problem of endogeneity of one or more explanatory variables, in particular the presence of the lagged dependent variable that gives a dynamic character to the panel specification. GMM estimation also provides solutions to the problems of simultaneity bias, inverse causality between different economic variables, and omitted variables. Indeed, not taking into account the problem of endogeneity in economic relations means making the strong assumption that, for example, the explanatory variables of the model are independent of the unobserved characteristics that distinguish the different countries.

There are, however, two estimators associated with GMMs. The first difference estimator (Arellano and Bond, 1991) and the system estimator (Blundell and Bond, 1998), which is an improved version of the first. One of the weaknesses of the first-difference estimator is that it is better suited for samples with sufficiently large $\mathrm{N}$ (individual dimension) and relatively small T (time dimension). It therefore has asymptotic precision weaknesses and instrument weaknesses that lead to biases in the finite samples.

The system estimator of Blundell and Bond (1998) simultaneously uses first difference and level equations to generate consistent estimators, even for finite samples, to overcome this problem. Differentiation eliminates the country-specific effect and thus the effect of omitted variables that are invariant over time. The first differences of the potentially endogenous explanatory variables are instrumented by their level lagged value, in order to reduce the simultaneity bias as well as the inverse causality bias, and under the assumption of no autocorrelation of errors in the level equation. 
The endogenous explanatory variables of the level model are instrumented by their most recent first difference (the use of other delayed first differences would lead to a redundancy of moment conditions), under the additional assumption of "quasi-stationarity" of these variables. Thus, the Generalized Method of Moments (GMM) in system developed by Blundell and Bond (1998) is used to estimate the model, the results of which are presented in the following section.

\section{3- Results And Discussion}

Table 3 presents the results of estimating Eq. (9) using the GMM in system.

\section{Tableau 2 : Estimation results}

\begin{tabular}{|c|c|c|}
\hline \multicolumn{3}{|c|}{ Endogenous variable = Agricultural value added per farm asset relative to poverty line } \\
\hline \multirow[t]{2}{*}{ L1.Irinc } & \multicolumn{2}{|l|}{$0.3081932 * \star$} \\
\hline & \multicolumn{2}{|l|}{$(2.47)$} \\
\hline \multirow[t]{2}{*}{ nagriresearch } & \multicolumn{2}{|l|}{$0.0730142 * \star$} \\
\hline & \multicolumn{2}{|l|}{$(2.46)$} \\
\hline \multirow[t]{2}{*}{ Irdinvest } & \multicolumn{2}{|l|}{ 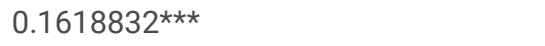 } \\
\hline & \multicolumn{2}{|l|}{$(2.21)$} \\
\hline \multirow[t]{2}{*}{ openr } & \multicolumn{2}{|l|}{0.0012139} \\
\hline & \multicolumn{2}{|l|}{$(0.43)$} \\
\hline \multirow[t]{2}{*}{ Inava } & \multicolumn{2}{|l|}{0.0216028} \\
\hline & \multicolumn{2}{|l|}{$(0.17)$} \\
\hline \multirow[t]{2}{*}{ Iprimedu } & \multicolumn{2}{|l|}{$0.0135461^{* \star *}$} \\
\hline & \multicolumn{2}{|l|}{$(2.71)$} \\
\hline \multirow[t]{2}{*}{ _cons } & \multicolumn{2}{|l|}{-2.324751} \\
\hline & \multicolumn{2}{|l|}{$(-0.61)$} \\
\hline Arellano-Bond test for $\mathrm{AR}(1)$ in first differences: & $z=-1.83$ & $\operatorname{Pr}>z=0.067$ \\
\hline Arellano-Bond test for AR(2) in first differences: & $z=0.87$ & $\operatorname{Pr}>z=0.383$ \\
\hline Sargan test of overid. restrictions: & $\operatorname{chi} 2(59)=34.91$ & Prob $>$ chi2 $=0.995$ \\
\hline Hansen test of overid. restrictions: & $\operatorname{chi} 2(59)=0.00$ & Prob $>$ chi $2=1.000$ \\
\hline$\star$ Significant at $10 \%, * \star$ Significant at $5 \%, * \star \star$ Sig & ficant at $1 \%$ & \\
\hline
\end{tabular}

The values in parentheses are the z-statistics of the normal distribution

To determine the significance of the model as part of an estimation using the GMM, the most important tests are Sargan's instrument validity test and the Arellano and Bond's second-order autocorrelation of residues test. The results show that the probability associated with the Sargan statistic is high (0.995). This makes it possible to confirm the validity of the instruments. Moreover, the results of the autocorrelation test of Arellano and Bond do not allow to accept the presence of second-order autocorrelation of residues (AR (2)) validating the use of appropriately delayed endogenous variables as instruments. In addition, the dynamic nature of the model cannot be rejected with respect to the coefficient associated with the delayed endogenous variable (L1.Ipaurur) which is positive and significant at $5 \%$. In fact, an increase in farm income of $1 \%$ at a given date results in an increase of the income of the following year by $0.31 \%$. This confirms the existence of dynamism and endogeneity in the modeling framework because the responsiveness of the current period's income compared to its value last year is high and significant.

As part of this modeling, public spending on research and development was mainly captured by two (02) proxies. These are public expenditures allocated to the administration of agricultural researchers and the number of agricultural researchers per 100,000 agricultural producers. The coefficients associated with these two (02) variables are all positive and significant at the $5 \%$ level. This reflects the positive influence of public funding for agricultural research and development on rural income. Thus, the results show that an increase in public 
funding for agricultural research and development is conducive to reducing rural poverty. Indeed, an increase of $1 \%$ (respectively one unit) in public expenditure on agricultural research and development (respectively number of agricultural researchers per hundred thousand producers) results in an increase in the rural income of $0.16 \%$ (respectively $0.07 \%$ ). These results are in line with our expectations. According to endogenous growth theory, research and development improves productivity and thus income. Indeed, increased spending on agricultural research and development not only promotes the development of new technologies, but also provides information to make new technologies more adoptable or better targeted to specific objectives and to improve policy making. In this scenario, the result would be an improvement in productivity that will lead to higher incomes through positive effects on consumer food prices, producer incomes and workers' wages (Winkleman, 1998). Hazell and Haddad (2001) argue that the research would affect poor farmers through increased production, allowing them to improve their diets and increase the supply of marketed products for higher farm income. Thus, an increase in public spending on agricultural research and development should result in an increase in the income level of the economy. Our results corroborate these theoretical predictions by highlighting the positive relationship between public spending on agricultural research and development and farmers' income. This is the case of some authors (Syed and Miyazako, 2013; Alene et al. 2009; Fan et al., 2004; Suphannachart and Warr, 2011) who have found similar results by showing in their studies that public spending on research and development is favourable to agricultural growth.

In addition to these two proxies, the effect of education (Iprimedu) on farm income was also considered. The coefficient linked to this variable is also positive and significant at the $1 \%$ threshold, reflecting a positive relationship between education and farm income. The increase in the primary completion rate by one unit translates into an increase in agricultural income of 0.01 unit. This result is in line with expectations and is explained by the fact that education allows farmers to adopt more productive techniques. It corroborates those of Moock (1981), Rauf (1991), Lau et al. (1991) who have shown the positive effects of education on agricultural productivity in developing countries.

The results also show that trade opening (topen) has a positive effect on farm income. When the open rate increases by one unit, farm income increases by $0.006 \%$. This result is explained by the fact that WAEMU Sates are major exporters of agricultural products. Côte d'Ivoire, for example, is the world's largest exporter of cocoa and cashew nuts. It is also important in the export of other agricultural products such as coffee, rubber, bananas and many others. Countries like Burkina Faso and Benin are major exporters of cotton. Thus, commercial openness facilitates the sale of these products to the outside helps to provide income to farmers. Indeed, the WAEMU States are not yet at the stage of industrialization that will allow local consumption of agricultural production. At this stage, in the absence of opening, it would be difficult for producers to sell the products locally. This could explain the positive relationship between trade openness and agricultural income in WAEMU countries.

The associated nonagricultural sector coefficient (Inava) is not significant. Thus, it can be inferred that in WAEMU countries the nonagricultural sector does not significantly affect farm income.

Despite the interesting results of this research, some shortcomings should be noted for future work. Indeed, the analysis period, which is 2000-2016, seems short. A longer series of data could provide a better understanding of the dynamics of rural poverty. Moreover, there is no consensus definition of poverty. Taking into account the multidimensional nature of poverty could lead to more interesting results.

\section{4- Conclusion And Policy Implications}

This paper focused on policies to reduce rural poverty through public financing of agriculture. In these countries, the majority of the poor lives in rural areas and operate mainly in the agricultural sector. This has guided the objective of this research to analyze the effects of public financing of agriculture on rural poverty alleviation in WAEMU States. Specifically, the paper focused on the effects of public spending in agricultural research and development on farm income.

For the empirical analysis, this research built a dynamic panel bringing together WAEMU countries from data covering the period 2000 - 1016. Based on the López (2004) model, which measures the effects of public spending on poverty, an empirical model has been derived to conduct the analysis. Since the panel is dynamic, the model was estimated using GMM in system developed by Blundel and Bond (1998), which seems more appropriate.

The results obtained are in line with expectations. Indeed, the expenditures allocated to the administration of agricultural researchers, the number of agricultural researchers per hundred thousand agricultural producers, the primary completion rate students have positive effects on agricultural income; which helps to reduce rural poverty. These results generate economic policy implications.

These States must establish a policy of training agricultural researchers to ensure the sustainability of research personnel in the agricultural sector. The World Bank (2008) has shown that agricultural research systems in sub-Saharan Africa are fragmented into almost 400 different research organizations, four times the number of agricultural research organizations in India and eight times that of the United States. This dispersion of researchers does not allow to benefit from a good synergy with agricultural advisory services in order to achieve economies of 
scale in research and is very expensive for these countries. It is therefore important for WAEMU to create large-scale regional research organizations as part of the implementation of its Common Agricultural Policy.

To make these centers work, countries need to support the financing. As a result, pooling each country's investments in research and development, for example, would enable the creation of centers of excellence and the dissemination of appropriate agricultural technologies for each type of agroecology. Given that the countries of the Union are similar in terms of constraints related to agricultural development, a regional center for research and development could develop appropriate technologies for the whole region.

In addition, WAEMU States must increase investments in the education sector through the construction of school infrastructure and the recruitment of competent staff to make education for all a reality and maintain students until the completion of the primary cycle. This would allow those who wish to operate in agriculture to have a minimum of skills to apply the different farming techniques to improve their productivity.

All of these recommendations challenge the WAEMU states, all development actors to pool efforts to make structuring investments in rural areas. It is in these environments that most of the poor live and must attract the attention of donors who want to reduce poverty. Investment in the agricultural sector would improve agricultural productivity, agricultural income and hence economic development.

Declarations

\section{Abbreviations}

\begin{tabular}{lll} 
AfDB & $:$ & African Development Bank \\
\hline BCEAO & $:$ & Banque Centrale des Etats de l'Afrique de l'Ouest \\
\hline FAO & $:$ & Food and Agriculture Organization of the United Nations \\
\hline FAOSTAT & $:$ & Food and Agriculture Organization Corporate Statistical Database \\
\hline GDP & $:$ & Gross Domestic Product \\
\hline GMM & $:$ & Generalized Method of Moments \\
\hline MDG & $:$ & Millennium Development Goals \\
\hline OLS & $:$ & Ordinary Least Squares \\
\hline WAEMU & $:$ & West Africa Economic and Monetary Union \\
\hline WDI & $:$ & World Development Indicator
\end{tabular}

\section{Declarations}

Funding:

Not applicable

\section{Conflicts of interest/Competing interests:}

The Authors declare that there is no conflict of interest

\section{Availability of data and materials:}

The datasets generated and/or analysed during the current study are available in the WDI, FAO; AFDB,repository, [https://databank.worldbank.org/source/world-development-indicators\#selectedDimension_DBList,https://knoema.com/atlas/sources/AfDB, http://www.fao.org/faostat/fr/\#data]

\section{Code availability:}

Stata 


\section{Authors' contributions:}

Ollo DAH proposed the theme and Boubié Toussaint BASSOLET validated it with clarifications. Ollo DAH collected, analysed and interpreted the data. Boubié Toussaint BASSOLET refined the results by improving the presentation of results and recommendations. All authors read and approved the final manuscript.

\section{Acknowledgements:}

Not applicable

\section{References}

1. Alene AM, Ajala SB-A, Olanrewaju A, Manyong V, Ndiaye A (2009) The Economic and Poverty Impacts of Maize Research in West and Central Africa. Agricultural Economics, P535-550

2. Amat A (2019) Dynamic Interactions Between Financial andMacroeconomic Imbalances: A Panel VAR Analysis. iiw Working Paper(162)

3. Andrianaivo M, Kpodar K (2011) Financial Inclusion, and Growth: Evidence from African Countries. IMF Working Paper(WP/11/73)

4. Arellano M, Bond SR (1991) Some tests of specification for panel data: Monte Carlo evidence and an application to employment Équations. Review of Économic Studies(58), 277-297

5. BCEAO (2012) Rapport sur la situation de la pauvreté dans les pays de l'UEMOA. Direction de la Recherche et de la Statistique, Dakar

6. Beintema N, Stads G (2004) Sub-Saharan African agricultural research Recent investment trends. Outlook on AGRICULTURE 33(4):239246

7. Beintema N, Stads G (2005) Les investissements dans la recherche agricole en Afrique subsaharienne: tendances récentes. ASTI/ISNAR/IFPRI, Washington

8. Bikienga I (2011) Problématique du financement de la recherche agricole face aux défis du développement agricole durable en Afrique. CEDRES, Ouagadougou

9. Blundell R, Bond S (1998) Initial Conditions and Moment Restrictions in Dynamic Panel Data Model. Journal of Econometrics(87), 115143

10. Boussard JM, Daviron B, Gérard F, Voituriez T (2006) Sécurité alimentaire et développement agricole en Afrique subsaharienne. FAO, Rome

11. Fan Sa (2008) Tracking Agricultural Spending for Agricultural Growth and Poverty Reduction in Africa. Washington: DC: Regional Strategic Analysis and Knowledge Support System. Available at

12. Fan S, Jitsuchon S, Methakunnavut N (2004) The Importance of Public Investment for Reducing Rural Poverty in Middle-Income Countries: The Case of Thailand. In: Development Strategy and Governance Division Discussion( $\left.N^{\circ} 7\right)$. International Food Policy Research Institute, Washington

13. Fan S, Zhang L, Zhang X (2004) Reforms, investment and poverty in rural China. Econ Dev Cult Change 52(N²):395-421

14. Kanbur R, Squire L (2000) The Evolution of Thinking about Poverty, inG. Meier and J. Stiglitz (eds.), Frontiers of Development Economics. OxfordUniversity Press, Oxford

15. López R (2004) Effect of the Structure of Rural Public Expenditures on Agricultural Growthand Rural Poverty in Latin America. InterAmerican Development Bank, Washington

16. Sanfo S (2010) Politiques publiques agricoles et lutte contre la pauvreté au Burkina Faso: le cas de la région du plateau central. Thèse de doctorat Université Paris 1 Panthéon-Sorbonne, France

17. Savadogo K, Bambio Y, Combary O, Ouedraogo A, Sawadogo J, Tiemtoré AZ (2012) Le niveau de vie des ménages en milieu rural du Burkina Faso dans le contexte de la décentralisation:Résultats de la première enquête intermédiaire PNGT2 2011. Ouagadougou: Laboratoire d'Analyse Quantitative Appliquée au Développement-Sahel (LAQAD-S) Université Ouaga II

18. Shyjan D (2007) Public investment and agricultural productivity: A state-wise analysis of food grains in India. (Working Paper 387)

19. Suphannachart W, Warr P (2011) research and productivity in Thai griculture. Australian Journal of Agricultural Resource Economics 55( $\left.\mathrm{N}^{\circ} 1\right): 35-52$

20. Syed S, Miyazako M (2013) Promoting investment in agriculture for increased Production and Productivity. FAO, Rome

21. Thirtle C, Lin L, Piesse J (2003) The impact of research-led agricultural productivity growth on poverty reduction in Africa, Asia and Latin America. Vol31, P 31959-1975. World Development

Page $11 / 12$ 
22. Timmer P (2009) A World without Agriculture - The Structural Transformation in Historical Perspective. American Enterprise Institute Press, Henry Wendt Lecture Series. Washington, DC

23. Wade I, Niang A (2014) L'engagement de Maputo: le mot d’ordre a-t-il été respecté? PASSERELLES, 15(3)

24. Konte MA, \& al (2017) Les déterminants du développement des marchés boursiers. RIELF(01)

25. Zmani M (2017) Libéralisation commerciale et investissement privé: une analyse en données de panel pour les entreprises manufacturières en Tunisie. Région et Développement(45) 